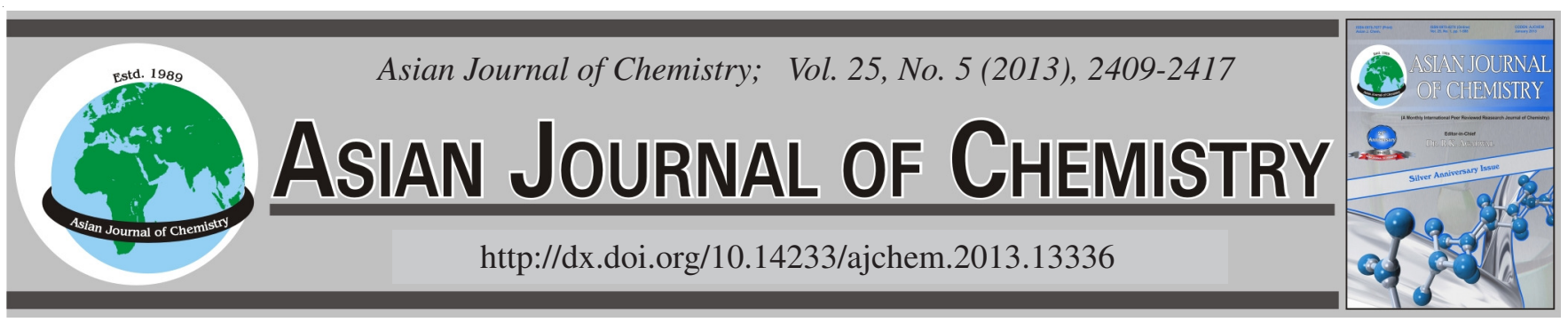

\title{
Biosorption of Arsenic by Mosambi (Citrus limetta) Peel: Equilibrium, Kinetics, Thermodynamics and Desorption Study
}

\author{
Suantak Kamsonlian ${ }^{1}$, S. Suresh ${ }^{2, *}$, C.B. Majumder ${ }^{1}$ and S. Chand ${ }^{1}$
}

${ }^{1}$ Department of Chemical Engineering, Indian Institute of Technology Roorkee, Roorkee-247 667, India

${ }^{2}$ Department of Chemical Engineering, Maulana Azad National Institute of Technology Bhopal, Bhopal-462 051, India

*Corresponding author: E-mail: sureshpecchem@gmail.com

(Received: 27 December 2011;

Accepted: 7 November 2012)

AJC-12370

\begin{abstract}
The removal of arsenic ions from aqueous solution onto the surface of mosambi peel as biosorbent. Fourier transformation infrared (FTIR), thermogravimetric (TGA) analysis and scanning electron microscopy (SEM) were used to characterize the surface of biosorbent. The effect of process parameters such as $\mathrm{pH}$, temperature, biosorbent dosage and contact time on the performance of biosorption was studied. The biosorbent used in this study was suitable for the removal of arsenic ions with maximum uptake capacity of $2.12 \mathrm{mg} \mathrm{g}^{-1}$ for $\mathrm{As}(\mathrm{III})$ and $3.32 \mathrm{mg} \mathrm{g}^{-1}$ for $\mathrm{As}(\mathrm{V})$ were obtained at $313 \mathrm{~K}$. Lower percentage removals of arsenic ions were observed with higher initial concentrations. At optimum conditions, the removal of $\mathrm{As}(\mathrm{III})$ and $\mathrm{As}(\mathrm{V})$ ions were $84.9 \%$ at $\mathrm{pH} 6$ and $89.1 \%$ at $\mathrm{pH} 4$, respectively. Equilibrium sorption data were found to be well fitted to Freundlich isotherm model. Dynamics studies established that the biosorption processes followed pseudo-second order rate equation. The thermodynamic properties of biosorption process were also determined. The values of these properties $\left(-\Delta \mathrm{G}^{\circ},+\Delta \mathrm{S}^{\circ}\right.$ and $\left.+\Delta \mathrm{H}^{\circ}\right)$ indicated that the biosorption process was spontaneous and endothermic in nature.
\end{abstract}

Key Words: Arsenic removal, Mosambi peel, Biosorption, Isotherm models, Kinetics and thermodynamics, Desorption.

ᄂ - - - - - - - - - - - - - - - - - - - - - - - - -

\section{INTRODUCTION}

Arsenic is found widely distributed in earth at concentration of nearly $2 \mathrm{mg} \mathrm{kg}^{-1}$ and having $20^{\text {th }}$ rank among the elements found in abundance in the earth crust ${ }^{1}$. Arsenic exists in the $-3,0,+3$ and +5 oxidation states ${ }^{2,3}$. Effluent of industries like metal-processing, semiconductor, copper smelting etc. and acid mine drainage wastewaters contain significant amount of arsenic $^{4}$. Heavy arsenic pollution in natural waters due to industrial effluents is a worldwide problem and has become an important issue and a matter of challenge for the environmental engineers and scientists. Its toxicity has been one of the worst environmental health hazards affecting the countries like India (West Bengal) and Bangladesh. Health effects are hyperpigmentation and keratosis, weakness, anaemia, burning sensation of eyes, solid swelling of legs (black foot disease), liver fibrosis, chronic lung disease, gangrene of toes, neuropathy ${ }^{5}$. Two forms are common in natural waters: As(III) and $\mathrm{As}(\mathrm{V})^{6}$ are commonly found in natural waters, in which As(III) is most toxic. The WHO and USEPA has recommended that the maximum contaminant level (MCL) for arsenic in drinking water be reduced to $10 \mu \mathrm{g} \mathrm{L}^{-17}$. Hence, it necessary to meet the maximum contaminant level value for the treatment of arsenic.
Many technologies, including co-precipitation with iron or alum, adsorption onto coagulated floc and ion exchange resins, reverse osmosis and membrane technologies and bio sorption have been used to remove arsenic from aqueous solution $^{8,9}$. In these methods, biosorption techniques are simple and convenient and have the potential for regeneration and sludge free operation. Several low cost and easily available biosorbents and agricultural wastes have been employed for the removal of toxic heavy metal ions. Most of the biosorption studies have focused on using shelled Moringa oleifera Lamarck seed powder ${ }^{10}$, Cambogia plant biomass ${ }^{11}$, rice polish $^{12}$, powder of stem of Acacia nilotica ${ }^{13}$, Tea fungal biomass ${ }^{14}$ etc. The study presented herein is aimed to remove arsenic ions by biosorption onto the surface of mosambi peel biomass from contaminated water. The mechanisms of arsenic biosorption from liquid media and study of sorption parameters ( $\mathrm{pH}$, contact time, temperature and dosage) were studied. The nature of sorption in terms of isotherm models, rate kinetics and thermodynamic aspects were also determined.

\section{EXPERIMENTAL}

All chemicals used in the present experiment were of analytical reagent (AR) grade. For preparation of stock solutions and dilutions, double deionized water (Millipore) 
was used. Stock solutions of $1000 \mathrm{~mL}$ concentration of both $\mathrm{As}(\mathrm{III})$ and $\mathrm{As}(\mathrm{V})$ were prepared from sodium meta arsenite $\left(\mathrm{As}_{2} \mathrm{O}_{3}\right)$ and sodium arsenate $\left(\mathrm{Na}_{2} \mathrm{HAsO}_{4} \cdot 7 \mathrm{H}_{2} \mathrm{O}\right)$, respectively.

\section{Bio-sorbent materials and characterization}

Biomass preparation: Fruit peel of mosambi biomass was collected from the fruit stall located in the campus of Indian Institute of Technology, Roorkee, India. The fruit peels were dried, crushed and washed thoroughly with double distilled water to remove the adhering dirt and finally dried in an air oven at $100-105{ }^{\circ} \mathrm{C}$ for $24 \mathrm{~h}$. After drying the biosorbents was sieved through 150-mesh size and analysis as such.

To understand the morphology of the peels, the scanning electron microscopy was carried out using a scanning electron microscope (QUANTA, Model 200 FEG, Netherland). Samples were gold sputtered using a sputter coater, (Edwards S150) and the SEM and the elementary analysis was done simultaneously using an EDAX Spectrometry. Textural characteristic of the peels was determined by nitrogen adsorption at 77.15 $\mathrm{K}$ using an automatic pulse chemisorption system (Micromeritics Chemisorb 2720). The Brunauer-Emmett-Teller (BET) surface area and monolayer pore volume of the Peels were determined using software available with the instrument. The functional groups in the peels were ascertained using FTIR spectrometer (Thermo Nicolet, NEXUS, USA) at room temperature. Pellet (pressed-disk) technique was used for this purpose. The spectral range was from $4000-400 \mathrm{~cm}^{-1}$. Thermogravimetric analysis of the samples was carried out using a DuPont Hi-Res TGA
2950, USA. About $10 \mathrm{mg}$ of the MP sample was uniformly spread over the crucible base in all the experimental runs. Under a heating rate of $10 \mathrm{~K} / \mathrm{min}$ and an oxidizing atmosphere (moisture-free air flowing at a rate of $200 \mathrm{~mL} / \mathrm{min}$ ), the samples were heated from the ambient temperature to $1000{ }^{\circ} \mathrm{C}$. The differential thermal gravimetry and differential thermal analysis data were recorded as a function of sample temperature and time, using the Pyris diamond software.

Batch biosorption studies: In the batch study, known amount of biosorbent was added to conical flask containing $100 \mathrm{mg} / \mathrm{L}$ initial arsenics concentration. Table-1 represents various sources of arsenic (surface/ground water, synthetic water and industrial wastewater) and its concentrations (mg/L) reported in literature and compares with the present investigation. The influence of $\mathrm{pH}$ was studied by varying $\mathrm{pH}$ value between $2-10$, by agitating $(150 \mathrm{rpm})$ the arsenic solutions i.e., $100 \mathrm{mg} / \mathrm{L}$ arsenic concentration of both $\mathrm{As}(\mathrm{III})$ and $\mathrm{As}(\mathrm{V})$ separately for $4 \mathrm{~h}$ at a temperature of $313 \mathrm{~K}$. The desired $\mathrm{pH}$ was adjusted with $1 \mathrm{~N} \mathrm{NaOH}$ and $1 \mathrm{~N} \mathrm{HCl}$ using a pH meter (pH 510 Eutech Instruments, Cyberscan). The percentage removal of arsenic ions was calculated as follows

$$
\text { Biosorption }(\%)=\frac{\left(\mathrm{C}_{\mathrm{i}}-\mathrm{C}_{\mathrm{f}}\right)}{\mathrm{C}_{\mathrm{i}}} \times 100
$$

where $C_{i}$ and $C_{f}$ are the initial and final concentrations of arsenic ions present in the biosorption studies.

Method of analysis: After the biosorption studies on effect of parameters viz., $\mathrm{pH}$, temperature, dose, initial concentration and contact time, the sample was filtered and the filtrate was

\begin{tabular}{|c|c|c|c|c|c|}
\hline \multicolumn{6}{|c|}{$\begin{array}{c}\text { TABLE-1 } \\
\text { VARIOUS ARSENIC CONCENTRATIONS REPORTED IN LITERATURE WITH PRESENT STUDY }\end{array}$} \\
\hline \multirow[b]{2}{*}{$\mathrm{pH}$} & \multirow[b]{2}{*}{ Sources } & Surface/ground water & Synthetic wastewater & Industrial wastewater & \multirow[b]{2}{*}{ Reference } \\
\hline & & $\begin{array}{l}\text { Arsenic conc. } \\
\left(\mathrm{mg} \mathrm{L}^{-1}\right) \text { or } \mathrm{ppm}\end{array}$ & $\begin{array}{l}\text { Arsenic conc. } \\
\left(\mathrm{mg} \mathrm{L}^{-1}\right) \text { or } \mathrm{ppm}\end{array}$ & $\begin{array}{l}\text { As conc. } \\
\left(\mathrm{mg} \mathrm{L}^{-1}\right) \text { or } \mathrm{ppm}\end{array}$ & \\
\hline 0.64 & Copper smelting & - & - & As $(T)=1978$ & Basha et al $^{37}$ \\
\hline- & Posa (Easter Slovakia) & As $(T)=0.230$ & - & - & Urik et $_{a l}{ }^{38}$ \\
\hline 6.6 & Thessaliniki, Greece & As $(T)=0.001$ & - & - & $\begin{array}{l}\text { Zouboulis and } \\
\text { Katsoyiannis }^{39}\end{array}$ \\
\hline 6.0 & Laboratory Experiment & - & $\begin{array}{l}\text { As }(\mathrm{III})=0.1 \\
\text { As }(\mathrm{V})=0.1\end{array}$ & - & $\begin{array}{l}\text { Prokhrel and } \\
\text { Viraraghavan }{ }^{40}\end{array}$ \\
\hline 7.0 & Laboratory Experiment & - & As $(V)=0.740$ & - & Deng and Ting ${ }^{41}$ \\
\hline $7.1 \pm 0.1$ & $\begin{array}{l}\text { Laboratory Experiment } \\
\text { based on West Bengal } \\
\text { groundwater }\end{array}$ & As $(T)=0.376$ & $\begin{array}{l}\text { As }(\mathrm{III})=0.188 \\
\text { As }(\mathrm{V})=0.188\end{array}$ & - & Mondal et $a l^{42}$ \\
\hline 2.3 & $\begin{array}{l}\text { Acid mine drainage } \\
\text { (Western Tasmania) }\end{array}$ & - & - & As $(T)=2.5$ & Gault et al ${ }^{43}$ \\
\hline $\begin{array}{l}6.5 \\
6.5\end{array}$ & Laboratory Experiment & - & $\begin{array}{l}\text { As }(\mathrm{III})=0.0125 \\
\text { As }(\mathrm{V})=0.0125\end{array}$ & - & Jeon et $_{\text {al }}{ }^{44}$ \\
\hline $\begin{array}{c}6.30 \\
7.7\end{array}$ & $\begin{array}{c}\text { Gold mining } \\
\text { (Stream sediments site, } \\
\text { Ghana) }\end{array}$ & - & - & $\begin{array}{c}\text { As }(T)=50 \\
\text { As }(T)=34253\end{array}$ & Wasay et $a^{45}$ \\
\hline $6.5-7.8$ & $\begin{array}{l}\text { Gold mining (Victoria, } \\
\text { Australia) }\end{array}$ & $\begin{array}{c}\text { As }(\mathrm{T})=0.145(\text { surface } \\
\text { water })\end{array}$ & - & - & Sultan and Dowling ${ }^{46}$ \\
\hline $6.8-7.0$ & $\begin{array}{l}\text { Wells at Chihuahua } \\
\text { Maxico City and El } \\
\text { Paso, Texas }\end{array}$ & As $(T)=0.075-0.134$ & - & - & Miramontes et $a l^{47}$ \\
\hline $2.0-8.0$ & $\begin{array}{l}\text { Six real groundwater at } \\
\text { West Bengal, India }\end{array}$ & As $(T)=0.04-0.18$ & - & - & Chakraborty et al ${ }^{48}$ \\
\hline $6.0-7.0$ & $\begin{array}{l}\text { Three real tubewells at } \\
\text { Jharkhand, India }\end{array}$ & As $(T)=0.026-0.063$ & - & - & Bhattacharjee et al ${ }^{49}$ \\
\hline $\begin{array}{l}7.0 \\
4.0\end{array}$ & Laboratory Experiment & - & $\begin{array}{l}\text { As }(I I I)=100 \\
\text { As }(V)=100\end{array}$ & - & Present study \\
\hline
\end{tabular}


analyzed for arsenic concentration by spectrophotometric method $^{15}$. Silver diethyl dithiocarbamate (SDDC) method was used for the analysis of arsenic solution (IS 3025: 1988 and ASTM D 2972: 2008). The detection limit of arsenic for SDDC method ranges from 5-250 $\mu \mathrm{g} / \mathrm{L}$ (ASTM D 2972: 2008) which also meet USEPA and WHO limit for drinking water of $10 \mu \mathrm{g} /$ $\mathrm{L}^{16,17}$. Aliquots of arsenic sample of necessary quantity depending upon the concentration were taken in arsenic generator flask. KI and $\mathrm{SnCl}_{2}$ were added for the reduction of $\mathrm{As}(\mathrm{V})$ to As(III). Finally zinc dust was added to form arsine gas, which was passed through a scrubber containing glass wool impregnated with lead acetate solution and then into an absorber tube containing a solution of silver diethyl dithiocarbamate in pyridine. Arsine reacting with these reagent formed reddish coloured silver solution and measured photometrically at wavelength $\left(\lambda_{\max }\right)$ of $540 \mathrm{~nm}$.

\section{RESULTS AND DISCUSSION}

Biosorbent characterization: The average particle size of peels was calculated to be $<1 \mathrm{~mm}$. Proximate analysis showed for mosambi peel biomass: $12.82 \%$ moisture, $87.12 \%$ volatile matter and $1.31 \%$ ash in blank-mosambi peel. Heating value of mosambi peel was found to be $5.03 \mathrm{MJ} / \mathrm{kg}$, respectively. The BET surface area of mosambi peel was found to be $1.121 \mathrm{~m}^{2} / \mathrm{g}$. Similar surface area has obtained in the modified orange peel and banana peel ${ }^{18}$. For structural and morphological characteristics, a SEM analysis were carried out for blank mosambi peel and As(III) and As(V)-loaded mosambi biomass (Fig. 1). The SEM analysis of mosambi peel confirmed that they have large number of pores on the surface with cracks and crevices. The surface modification of As(III) and As(V)loaded mosambi peel led to variation in morphology, like the structure of the surface (few pores are filled). EDX analysis of biosorption has been represented (not shown). It showed the morphology behaviour of adsorption onto the mosambi peel and percentage weight of chemical compositions available on the surface of mosambi peel were as follows: $40.21 \%$ of $\mathrm{C}$, $48.32 \%$ of $\mathrm{O}, 5.13 \%$ of $\mathrm{Si}, 4.11 \%$ of $\mathrm{Ca}, 1.50 \%$ of $\mathrm{Na}$ and $0.94 \%$ of $\mathrm{Mg}$.

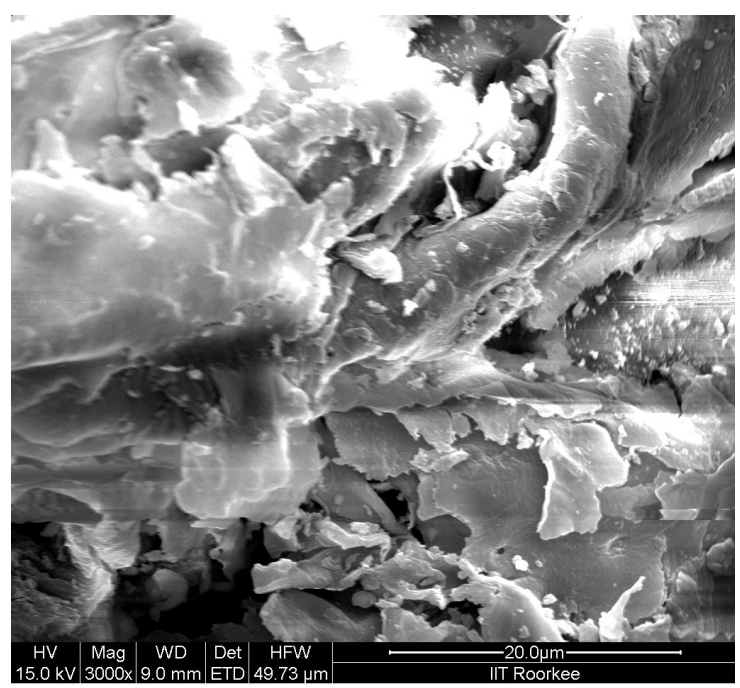

(a) Fresh mosambi peel biomass

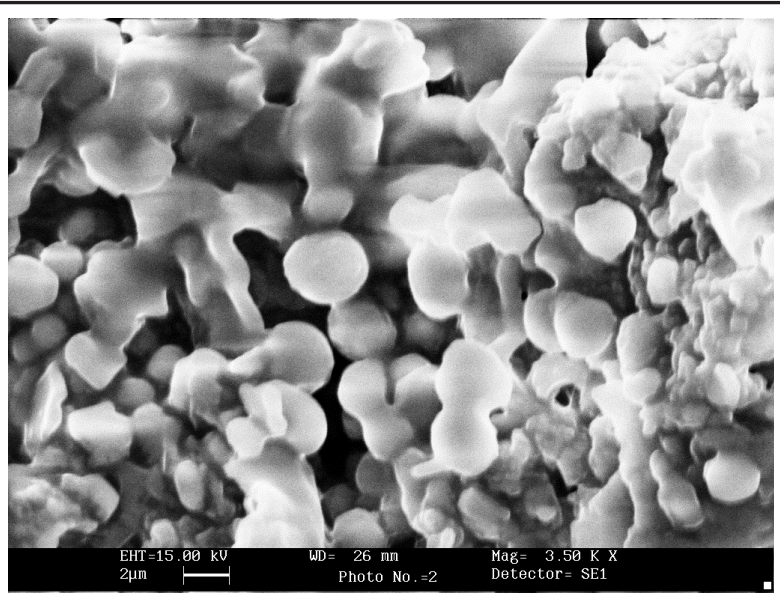

(b) As(III)-loaded mosambi peel biomass

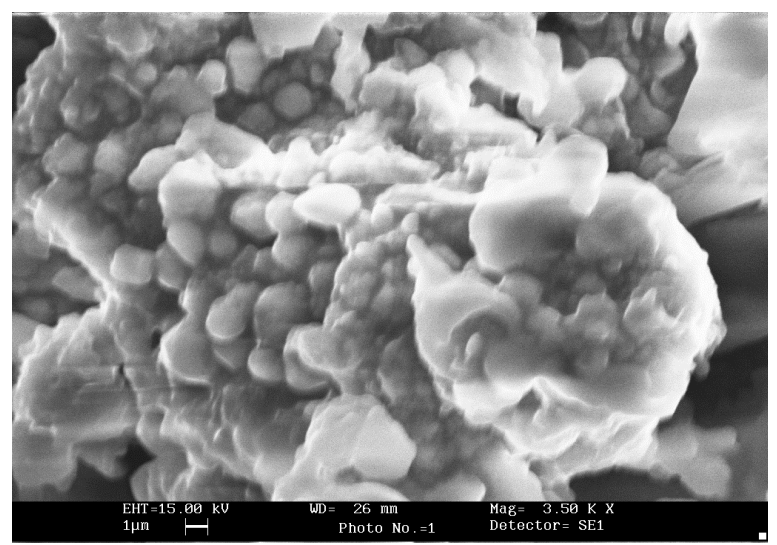

(c) As(V)-loaded loaded mosambi peel biomass

Fig. 1. SEM images of fresh mosambi peel biomass and loaded mosambi biomass

Thermogravimetry was used to study the thermal degradation characteristics of peels. The TGA, DTA and DTG curves of the banana peel and orange peel at a heating rate of $10 \mathrm{~K} / \mathrm{min}$ are shown in Fig. 2. Upto $373 \mathrm{~K}$, a mass loss of $5 \%$ was found due to loss of residual moisture content of the sample. During 523-745 K, there was a sharp fall in weight from 91.5-21.7\% due to the loss of volatile matter and oxidative degradation. Beyond $745 \mathrm{~K}$, the weight loss was steady but slow, giving $c a$. $0.4 \%$ weight loss from 745 to $1292 \mathrm{~K}$ (ash formation). At 700 $\mathrm{K},-2.90 \mathrm{~J} / \mathrm{mg}$ of heat is evolved due to the oxidation of carbonaceous substances present in the bio-sorbent surface as illustrated in DTA curve ${ }^{19}$. Banana peel and orange peel do not show any endothermic transition between room temperature and $523 \mathrm{~K}$, indicating the lack of any crystalline or other phase changes during the heating process. The broad peak observed from the first derivative loss curve (DTG) may be due to the combustion of carbon species. It is necessary to properly dispose of the spent-mosambi peel and/or utilize it for some beneficial purpose, if possible. This is essential due to hazardous nature of the spent- mosambi peel. FTIR spectrum analysis was conducted at 32 cumulative scans to find out the types of functional groups present onto the biosorbent surface (Fig. 3). Functional groups like hydroxyl, amide, amine, carboxyl, ketonic, aromatic and aliphatic stretching were observed in the biosorbent surface as shown in Table-2. Similar results were found by other researchers ${ }^{20,21}$. Similar 


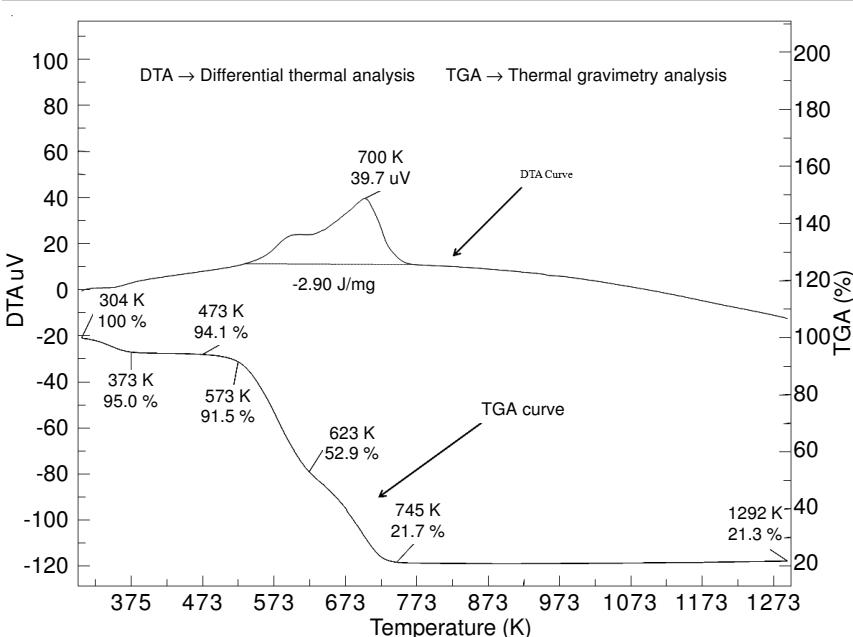

Fig. 2. TGA-DTA graphs of mosambi peel biomass under oxidizing atmosphere

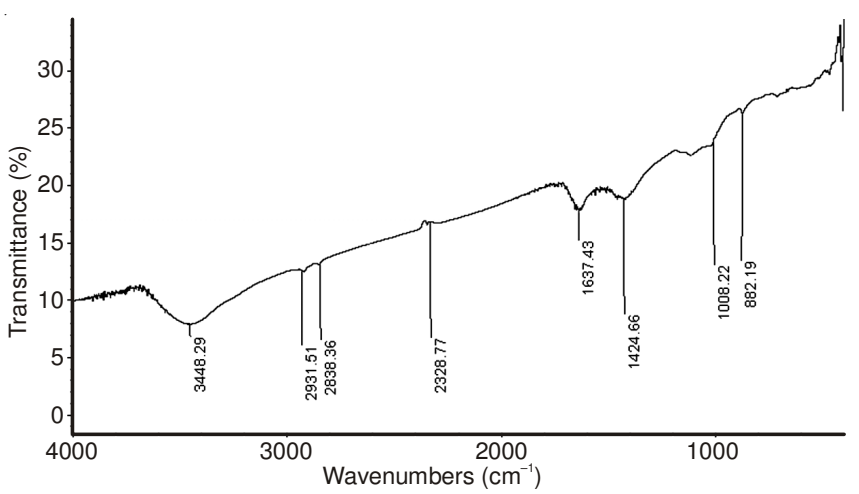

Fig. 3. FTIR of mosambi biomass

TABLE-2

FTIR SPECTRUM ANALYSIS OF MOSAMBI PEEL BIOMASS

\begin{tabular}{cc}
\hline IR peak of mosambi biomass $\left(\mathrm{cm}^{-1}\right)$ & Assignment \\
\hline 3448 & O-H and $-\mathrm{N}-\mathrm{H}$ \\
$2931-2328$ & $\mathrm{CH}_{3} / \mathrm{C}-\mathrm{H}$ asymmetric \\
& stretching vibration \\
$1637-1424$ & $\mathrm{C}-\mathrm{C} / \mathrm{N}-\mathrm{C}$ stretching \\
$1008-882$ & $\mathrm{C}-\mathrm{O}$ stretching \\
882 & Oxygen-bond \\
\hline
\end{tabular}

peaks were observed on the biosorption of $\mathrm{As}(\mathrm{V})$ by dried orange peel ${ }^{22}$. Absorption wave number of peaks at 3,295.26 and $1,605.27 \mathrm{~cm}^{-1}$, respectively indicative of a fact that these groups play a role in biosorption process. As(V) loaded orange peel show a small peak at $877.32 \mathrm{~cm}^{-1}$ may attributed to the metal oxygen bond ${ }^{23}$.

Effect of pH: The uptake capacity of As(III) and As(V) species by biosorbent was found to be $\mathrm{pH}$ dependent. Fig. 4 shows the percentage removal of arsenic against various $\mathrm{pH}$. Maximum sorption of $\mathrm{As}(\mathrm{III})$ ion occurred in the range of $\mathrm{pH}$ 6-8. Slight decrease was observed at higher $\mathrm{pH}(>\mathrm{pH} 8)$ due to less electrostatic attractions and maximum sorption of $\mathrm{As}(\mathrm{V})$ ion was occurred at $\mathrm{pH} 4$. Decreased in percentage removal of $\mathrm{As}(\mathrm{V})$ ion beyond $\mathrm{pH} 4$ was observed due to electrostatic repulsion between the negatively charged $\mathrm{As}(\mathrm{V})$ species and the bio-sorbent surface. Thus, $\mathrm{pH} 6$ and $\mathrm{pH} 4$ were considered as an optimum $\mathrm{pH}$ for $\mathrm{As}(\mathrm{III})$ and $\mathrm{As}(\mathrm{V})$ for removal of arsenic ions from contaminated water. From the literature reports, the maximum uptake of As(III) occurred at neutral conditions ( $\mathrm{pH}$

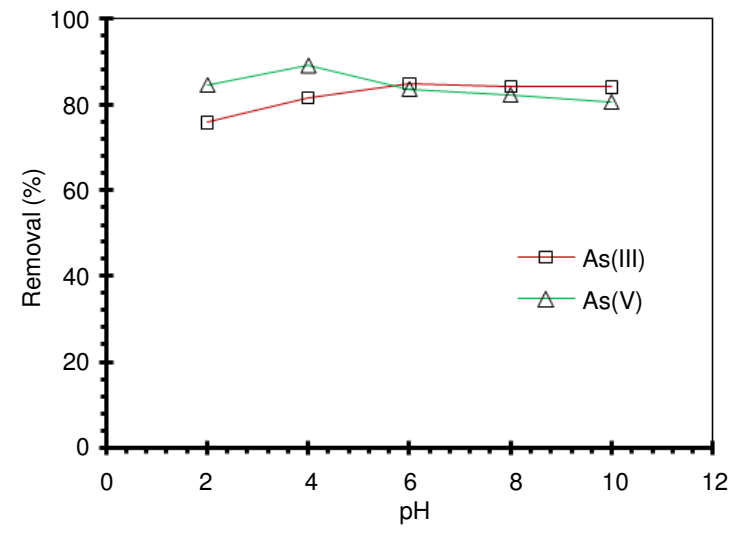

Fig. 4. Effect of $\mathrm{pH}$ on biosorption of arsenic ions $(\mathrm{Ci}, \mathrm{As}(\mathrm{III})=100 \mathrm{mg} / \mathrm{L}$, $\mathrm{Ci}, \operatorname{As}(\mathrm{V})=100 \mathrm{mg} / \mathrm{L}, \mathrm{P}_{\mathrm{c}}=1.18 \mathrm{~mm}-425 \mu \mathrm{m}, \mathrm{D}_{\mathrm{c}}=1 \mathrm{~g}, \mathrm{t}_{\mathrm{c}}=4 \mathrm{~h}, \mathrm{rpm}$ $=150$ )

of ca. 6-8) and for $\mathrm{As}(\mathrm{V})$ acidic conditions ( $\mathrm{pH}$ nearly 4) were favourable ${ }^{24,25}$.

Effect of biosorbent: Experiments were performed by varying the quantity of biosorbent between $10-50 \mathrm{~g} / \mathrm{L}$ of As(III) solution and $\mathrm{As}(\mathrm{V})$ solution, separately with $100 \mathrm{mg} / \mathrm{L}$ initial concentration of arsenics at $150 \mathrm{rpm}$. Fig. 5 shows that the percentage removal of arsenic increases with the increase in the dosage of biosorbent upto $30 \mathrm{~g} / \mathrm{L}$ for As(III) and upto 40 $\mathrm{g} / \mathrm{L}$ for $\mathrm{As}(\mathrm{V})$. This is mainly due to the increase in surface area and availability of more active sites ${ }^{9}$. The optimum percentage removal of $\mathrm{As}(\mathrm{III})$ and $\mathrm{As}(\mathrm{V})$ was achieved at 30 and $40 \mathrm{~g} / \mathrm{L}$, respectively. Beyond the optimum dosage, there was lesser removal of arsenic ion due to saturation of pores at the surface of biosorbent. Though optimum biosorbent dosages of As(III) and As(V) were obtained as 30 and $40 \mathrm{~g} / \mathrm{L}$, respectively per litre of solution, respectively, $10 \mathrm{~g} / \mathrm{L}$ dosage was chosen to compare the withdrawal capacity of arsenic at exhaust point. However, an optimum dosage of biosorbents has been used in further studies.

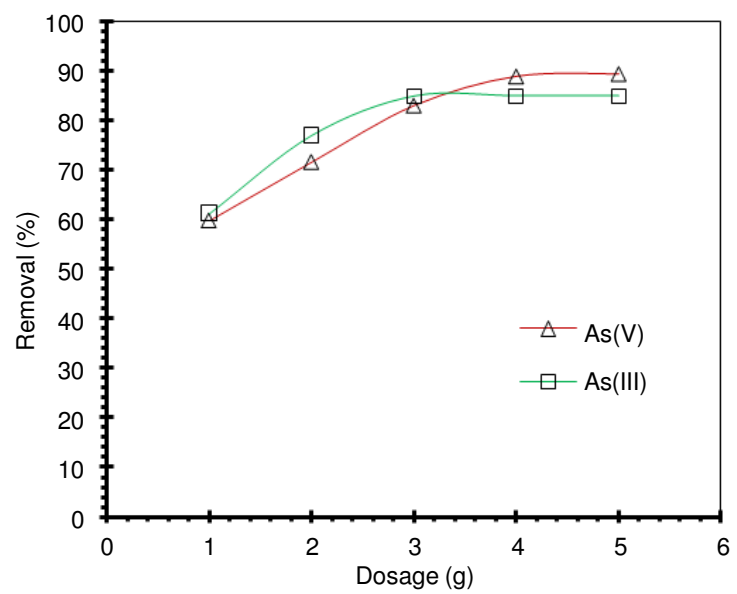

Fig. 5. Effect of dosage on biosorption of arsenic ions $\left(\mathrm{C}_{\mathrm{i}}, \mathrm{As}(\mathrm{III})=100\right.$ $\mathrm{mg} / \mathrm{L}, \mathrm{C}_{\mathrm{i}}, \mathrm{As}(\mathrm{V})=100 \mathrm{mg} / \mathrm{L}, \mathrm{P}_{\mathrm{c}}=1.18 \mathrm{~mm}-425 \mu \mathrm{m}, \mathrm{t}_{\mathrm{c}}=4 \mathrm{~h}, \mathrm{rpm}=$ 150)

Effect of contact time: Contact time studies were conducted between $0-15 \mathrm{~h}$ to determine the biosorption capacity of the material by considering the agitation period of the biosorbent at the solid liquid interface. $1 \mathrm{~g}$ of biosorbent was 
suspended in $100 \mathrm{~mL}$ of solution for both $\mathrm{As}(\mathrm{III})$ and $\mathrm{As}(\mathrm{V})$ separately with initial concentration of $100 \mathrm{mg} / \mathrm{L}$. The percentage removal of arsenic species at various contact times is plotted in Fig. 6. At the initial stage of experiment rapid removal of arsenic species was obtained which subsequently slowed down and finally stabilized beyond $4 \mathrm{~h}$. The results may be due to the presence of more active sites initially, which decreased due to the accumulation of arsenic species and saturation of filled active sites. Results suggest that $4 \mathrm{~h}$ contact time was sufficient for mosambi peel peel for the biosorption of arsenic from liquid phase.

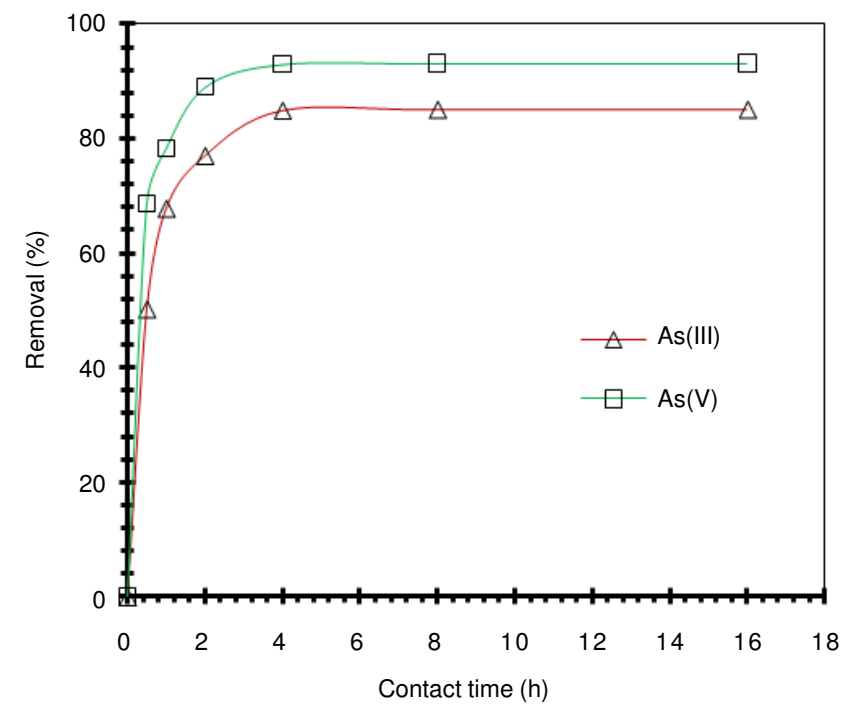

Fig. 6. Effect of contact time on biosorption of arsenic ions $(\mathrm{Ci}, \mathrm{As}(\mathrm{III})=$ $100 \mathrm{mg} / \mathrm{L}, \mathrm{C}_{\mathrm{i}}, \mathrm{As}(\mathrm{V})=100 \mathrm{mg} / \mathrm{L}, \mathrm{P}_{\mathrm{c}}=1.18 \mathrm{~mm}-425 \mu \mathrm{m}, \mathrm{D}_{\mathrm{c}}=1 \mathrm{~g}$, $\mathrm{rpm}=150)$

Effect of temperature: The removal efficiency was highly dependent on the initial concentration of $\mathrm{As}(\mathrm{III})$ and $\mathrm{As}(\mathrm{V})$ and temperature of sample solution. In present study, the initial concentration of the solution was varied between 50 and $200 \mathrm{mg} / \mathrm{L}$ and temperature was varied between 293 and $318 \mathrm{~K}$ for both $\mathrm{As}(\mathrm{III})$ and $\mathrm{As}(\mathrm{V})$. The effect of temperature on biosorption of arsenic ions onto the surface of peel was studied from 293-318 K (Fig. 7). It was observed that with the increase in temperature, removal of arsenic species increases upto $313 \mathrm{~K}$, but decreased in arsenic ions removal occurred at higher temperature due to breaking down of arsenic ions bond on the bio-sorbent surface ${ }^{26}$. Temperature of the sorption medium is important for energy dependent mechanisms in biosorption $^{27,28}$. For this reason, three temperatures viz., 293, 303 and $313 \mathrm{~K}$ have been chosen to carry out equilibrium studies.

Equilibrium studies: Sorption equilibrium is established when the amount of solute being adsorbed onto the biosorbent is equal to the amount being desorbed. Sorption equilibrium study provides fundamental physicochemical results to evaluate the applicability of sorption processes as a unit operation ${ }^{29}$. In this study, Langmuir, Freundlich and Redlich-Peterson isotherm models were used to describe the relationship between the amount adsorbed onto the surface of mosambi peel and its equilibrium concentration in liquid media ${ }^{30}$. Langmuir isotherm model assumes that there are finite numbers of binding

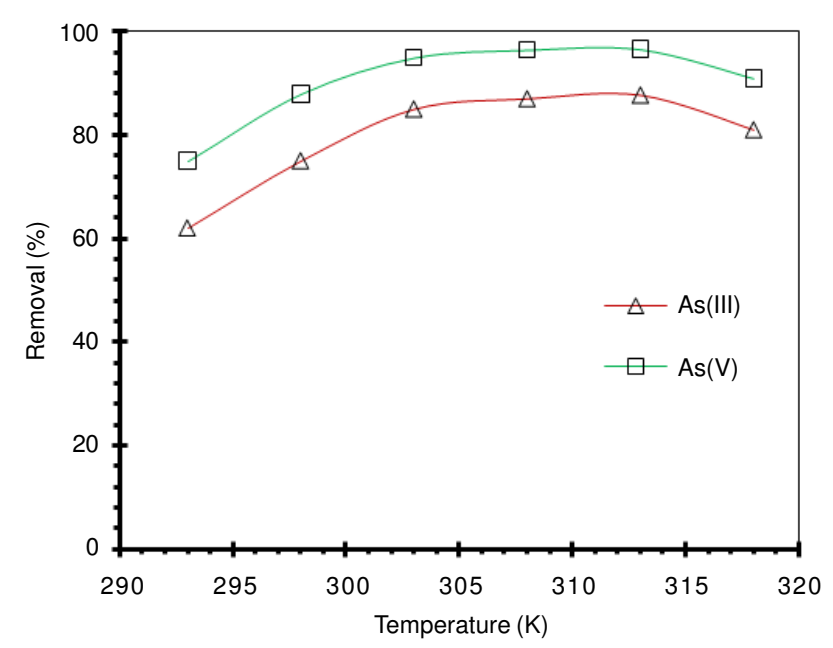

Fig. 7. Effect of temperature on biosorption of arsenic ions $\left(\mathrm{C}_{\mathrm{i}}, \mathrm{As}(\mathrm{III})=\right.$ $100 \mathrm{mg} / \mathrm{L}, \mathrm{C}_{\mathrm{i}}, \mathrm{As}(\mathrm{V})=100 \mathrm{mg} / \mathrm{L}, \mathrm{P}_{\mathrm{c}}=1.18 \mathrm{~mm}-425 \mu \mathrm{m}, \mathrm{t}_{\mathrm{c}}=4 \mathrm{~h}$, $\mathrm{rpm}=150$ )

sites having the same affinity for mono layer adsorption and there is no interaction between adsorbed molecules ${ }^{31}$. It is given by the equation

$$
\mathrm{q}_{\mathrm{e}}=\frac{\mathrm{K}_{\mathrm{L}} \times \mathrm{C}_{\mathrm{e}}}{\left(1+\mathrm{b} \times \mathrm{C}_{\mathrm{e}}\right)}
$$

where $\mathrm{K}_{\mathrm{L}}$ and $\mathrm{b}$ are the maximum uptake capacity $(\mathrm{mg} / \mathrm{g})$ and Langmuir constant related to the capacity $(\mathrm{L} / \mathrm{mg})$, respectively. $\mathrm{C}_{\mathrm{e}}$ is the equilibrium arsenic concentration $(\mathrm{mg} / \mathrm{L})$.

The linearization of eqn. 2 results

$$
\frac{\mathrm{C}_{\mathrm{e}}}{\mathrm{q}_{\mathrm{e}}}=\frac{1}{\mathrm{~b} \times \mathrm{K}_{\mathrm{L}}}+\frac{\mathrm{C}_{\mathrm{e}}}{\mathrm{K}_{\mathrm{L}}}
$$

Freundlich isotherm model expresses the heterogeneity of the adsorbent material ${ }^{14}$. Mathematical expression of Freundlich model can be expressed as

$$
\mathrm{q}_{\mathrm{e}}=\mathrm{K}_{\mathrm{f}} \times \mathrm{C}_{\mathrm{e}}^{(1 / \mathrm{n})}
$$

where $\mathrm{K}_{\mathrm{f}}$ and $\mathrm{n}$ are constants for adsorption capacity (L/mg) and adsorption intensity, respectively.

Linear form of eqn. 4 can be expressed as

$$
\log \mathrm{q}_{\mathrm{e}}=\log \mathrm{K}_{\mathrm{f}}+\frac{1}{\mathrm{n}} \log \mathrm{C}_{\mathrm{e}}
$$

The Redlich-Peterson isotherm incorporates three parameters into empirical isotherm and can be applied either to homogenous or heterogonous systems.

$$
\mathrm{q}_{\mathrm{e}}=\frac{\left(\mathrm{K}_{\mathrm{R}}+\mathrm{C}_{\mathrm{e}}\right)}{\left(1+\mathrm{Y}_{\mathrm{R}} \times \mathrm{C}_{\mathrm{e}}^{\mathrm{p}}\right)}
$$

where $\mathrm{q}_{\mathrm{e}}$ is equilibrium uptake $(\mathrm{mg} / \mathrm{g}), \mathrm{Y}_{\mathrm{R}}$ and $\mathrm{K}_{\mathrm{R}}$ are RedlichPeterson isotherm constants $(\mathrm{L} / \mathrm{mg}), \mathrm{p}$ is the heterogeneity constant $(0<\mathrm{p}<1)$ and $\mathrm{C}_{\mathrm{e}}$ is equilibrium liquid phase concentration $(\mathrm{mg} / \mathrm{L})$.

In this study the batch isothermal data fitted to the isotherm models were solved by using the curve fitting toolbox of MATLAB program as shown in Table-3. Figs. 8 and 9 represent the isotherm curves at various temperatures and initial concentrations varied from $50-200 \mathrm{mg} / \mathrm{L}$. Batch studies of biosorption of arsenic onto mosambi peel biomass followed 


\begin{tabular}{|c|c|c|}
\hline \multicolumn{3}{|c|}{$\begin{array}{l}\text { TABLE-3 } \\
\text { SUMMARY OF BIOSORPTION ISOTHERM PARAMETERS FOR As(III) AND As(V) ONTO MOSAMBI PEEL (MP) } \\
\text { BIOMASS AT VARIOUS TEMPERATURES }\left(C_{\mathrm{i}}=50-200 \mathrm{mg} \mathrm{L}^{-1}, \mathrm{t}_{\mathrm{c}}=4 \mathrm{~h} \text { AND } 150 \mathrm{rpm}\right)\end{array}$} \\
\hline Isotherm model & Temperature $(\mathrm{K})$ & Model parameters \\
\hline Langmuir model: As (III) & $\begin{array}{l}293 \\
303 \\
313\end{array}$ & $\begin{array}{l}\mathrm{K}_{\mathrm{L}}=3.042 ; b=0.0309 ; \mathrm{R}^{2}=0.997 \\
\mathrm{~K}_{\mathrm{L}}=2.681 ; \mathrm{b}=0.2733 ; \mathrm{R}^{2}=0.933 \\
\mathrm{~K}_{\mathrm{L}}=3.108 ; \mathrm{b}=0.2924 ; \mathrm{R}^{2}=0.942\end{array}$ \\
\hline Langmuir model: As(V) & $\begin{array}{l}293 \\
303 \\
313\end{array}$ & $\begin{array}{l}\mathrm{K}_{\mathrm{L}}=2.783 ; \mathrm{b}=0.136 ; \mathrm{R}^{2}=0.956 \\
\mathrm{~K}_{\mathrm{L}}=3.02 ; \mathrm{b}=0.3809 ; \mathrm{R}^{2}=0.983 \\
\mathrm{~K}_{\mathrm{L}}=3.111 ; \mathrm{b}=0.8119 ; \mathrm{R}^{2}=0.918\end{array}$ \\
\hline Freundlich model: As(III) & $\begin{array}{l}293 \\
303 \\
313\end{array}$ & $\begin{aligned} \mathrm{K}_{\mathrm{f}} & =0.38 ; \mathrm{n}=2.558 ; \mathrm{R}^{2}=0.990 \\
\mathrm{~K}_{\mathrm{f}} & =1.116 ; \mathrm{n}=5.329 ; \mathrm{R}^{2}=0.990 \\
\mathrm{~K}_{\mathrm{f}} & =1.199 ; \mathrm{n}=4.691 ; \mathrm{R}^{2}=0.999\end{aligned}$ \\
\hline Freundlich model: As(V) & $\begin{array}{l}293 \\
303 \\
313\end{array}$ & $\begin{array}{l}\mathrm{K}_{\mathrm{f}}=0.889 ; \mathrm{n}=4.278 ; \mathrm{R}^{2}=0.990 \\
\mathrm{~K}_{\mathrm{f}}=1.409 ; \mathrm{n}=6.031 ; \mathrm{R}^{2}=0.993 \\
\mathrm{~K}_{\mathrm{f}}=1.722 ; \mathrm{n}=7.598 ; \mathrm{R}^{2}=0.994\end{array}$ \\
\hline Redlich-Peterson model: As(III) & $\begin{array}{l}293 \\
303 \\
313\end{array}$ & $\begin{array}{l}K_{R}=0.334 ; Y_{R}=0.576 ; p=0.6895 ; R^{2}=0.990 \\
K_{R}=1.270 ; Y_{R}=0.737 ; p=0.9034 ; R^{2}=0.992 \\
K_{R}=2.478 ; Y_{R}=1.550 ; p=0.8497 ; R^{2}=0.999\end{array}$ \\
\hline Redlich-Peterson model: As(V) & $\begin{array}{l}293 \\
303 \\
313\end{array}$ & $\begin{array}{c}K_{R}=0.798 ; Y_{R}=0.559 ; p=0.858 ; R^{2}=0.982 \\
K_{R}=1.13 ; Y_{R}=0.367 ; p=1.004 ; R^{2}=0.999 \\
K_{R}=2.056 ; Y_{R}=0.539 ; p=1.048 ; R^{2}=0.845\end{array}$ \\
\hline
\end{tabular}

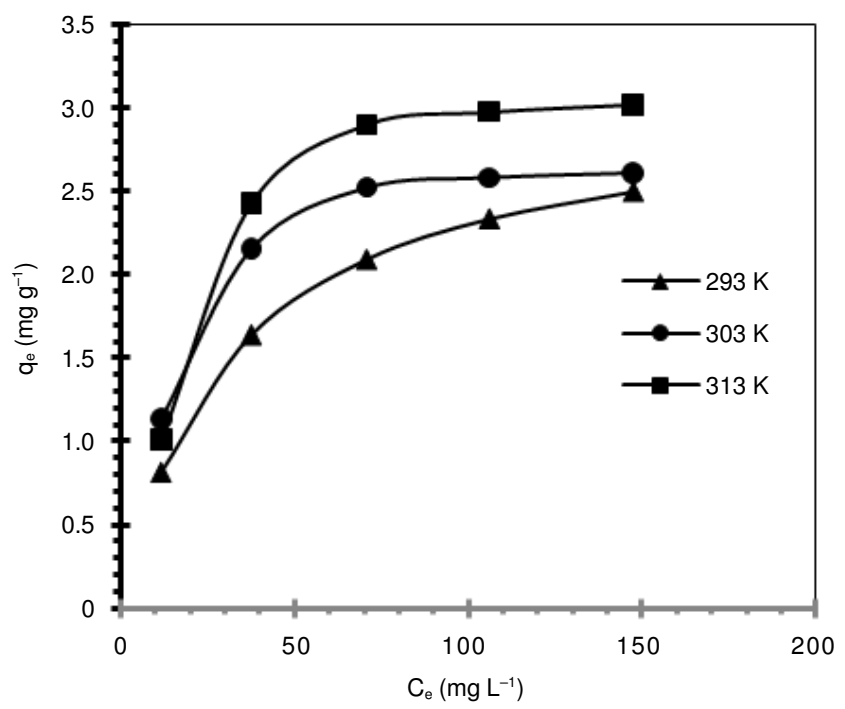

(a)

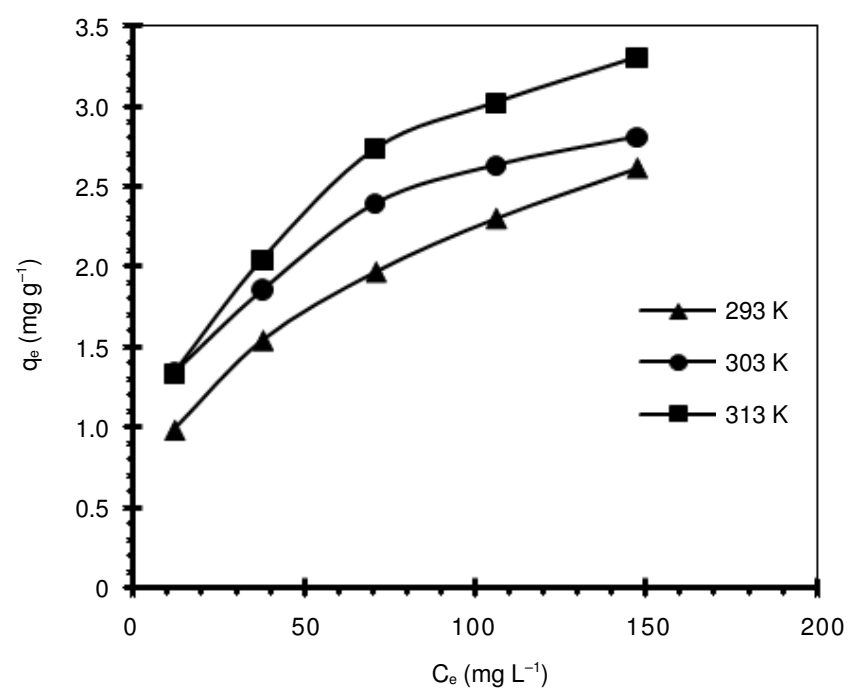

(b)

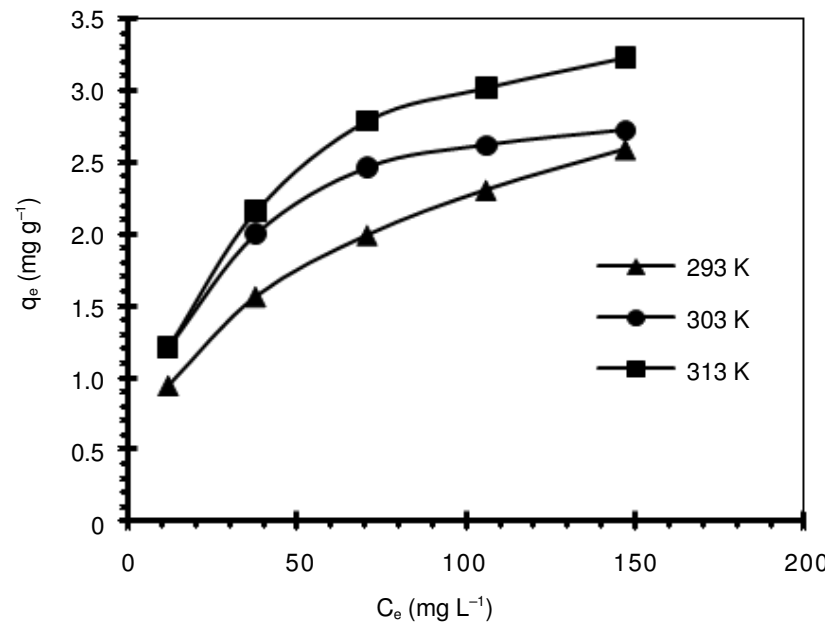

(c)

Fig. 8. Isotherm models for As(III) ion removal mediated by biosorption onto mosambi peel biomass surface at various temperatures (particle size $=1.18 \mathrm{~mm}$, agitation rate $=150 \mathrm{rpm}, \mathrm{pH} 6$ and contact time $=$ 4 h). (a) Langmuir isotherm model, (b) Freundlich isotherm model and (d) Redlich-Peterson isotherm model

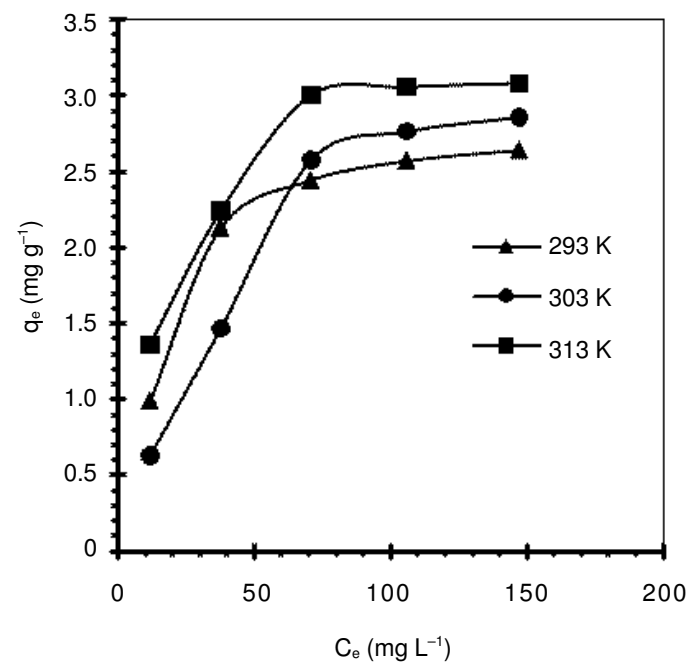

(a) 


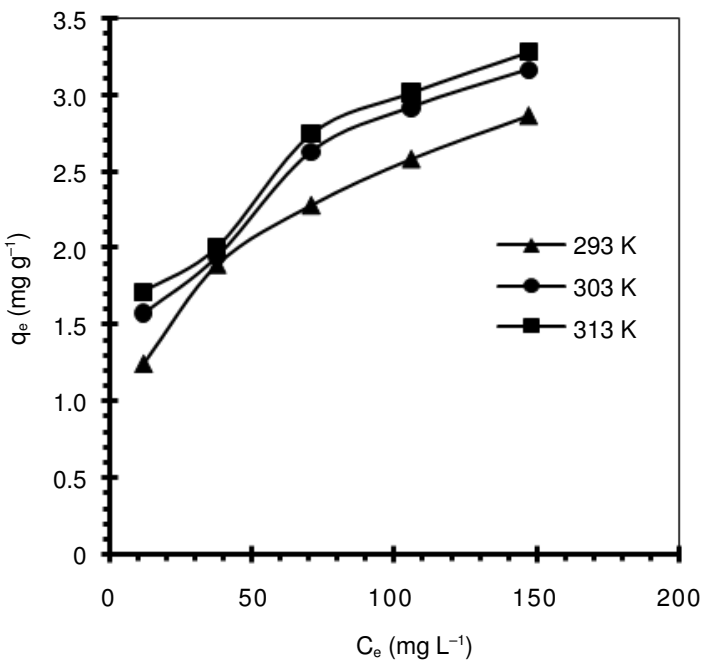

(b)

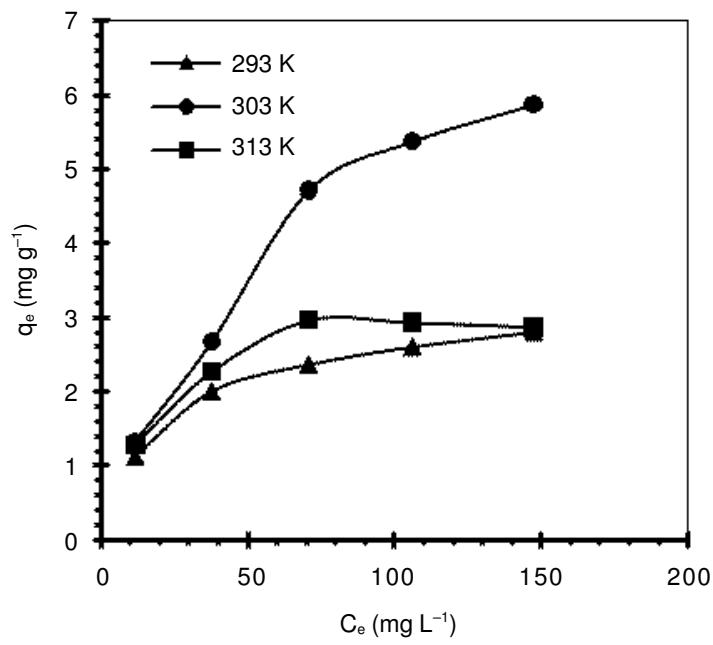

(c)

Fig. 9. Isotherm models for $\mathrm{As}(\mathrm{V})$ ion removal mediated by biosorption onto mosambi peel biomass surface at various temperatures (particle size $=1.18 \mathrm{~mm}$, agitation rate $=150 \mathrm{rpm}, \mathrm{pH} 4$ and contact time $=$ 4 h). (a) Langmuir isotherm model, (b) Freundlich isotherm model and (c) Redlich-Peterson isotherm model

Freundlich isotherm model best with high linear regression coefficients $\left(\mathrm{R}^{2}\right)$ for both $\mathrm{As}(\mathrm{III})$ and $\mathrm{As}(\mathrm{V})$ ions at various temperatures, which indicates that biosorption occurred on heterogeneous surface of solid biomass Similar isotherm was found for copper biosorption onto orange residue ${ }^{26}$.

Kinetic studies: The sorption of organic molecules from liquid phase to solid phase can be considered as reversible process with equilibrium being established between the solution and solid phase. Assuming a non dissociating molecular sorption of sorbate onto sorbent particle, the sorption phenomenon can be described as the diffusion controlled process. The Lagergren pseudo first order model ${ }^{32,33}$ can be expressed as

$$
\frac{\mathrm{dq}}{\mathrm{dt}}=\mathrm{K}_{1}\left(\mathrm{q}_{\mathrm{e}}-\mathrm{q}\right)
$$

where $K_{1}$ is the pseudo first order rate constant $\left(\mathrm{min}^{-1}\right)$. The graph of pseudo second order model has been represented in Fig. 10(a). The pseudo second order model can be represented in the following form

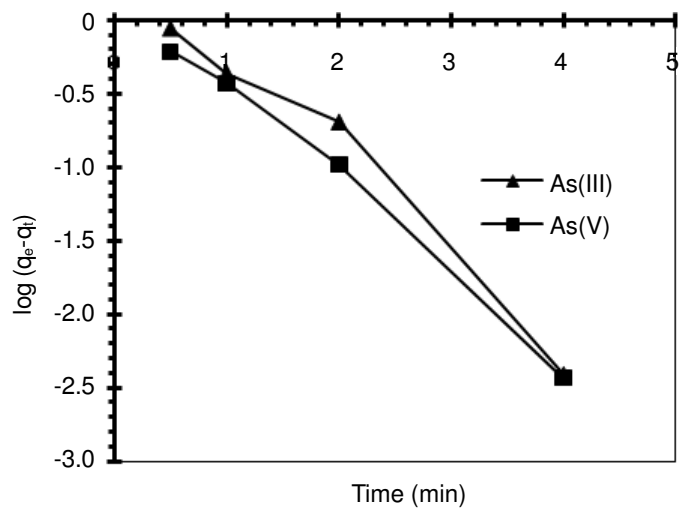

(a)



(b)

Fig. 10. Study of kinetic reaction model $(\mathrm{pH} \mathrm{As}(\mathrm{III})=6, \mathrm{pH} \mathrm{As}(\mathrm{III})=4$, temperature $=313 \mathrm{~K}$ and $150 \mathrm{rpm}$ ). (a) pseudo first order model and (b) pseudo second order model

$$
\frac{\mathrm{dq}}{\mathrm{dt}}=\mathrm{K}_{2}\left(\mathrm{q}_{\mathrm{e}}-\mathrm{q}\right)^{2}
$$

where $\mathrm{K}_{2}$ is the pseudo second order rate constant ( $\mathrm{g} / \mathrm{mg} \mathrm{min}$ ). On integrating at boundary conditions the following equation obtained

$$
\frac{\mathrm{t}}{\mathrm{dt}}=\frac{1}{\left(\mathrm{~K}_{2} \times \mathrm{q}_{\mathrm{e}}^{2}\right)}+\frac{\mathrm{t}}{\mathrm{q}_{\mathrm{e}}}
$$

The initial sorption rate, $\mathrm{h}$ ( $\mathrm{g} / \mathrm{mg} \min )$, as $\mathrm{t} \rightarrow 0$ can be defined as

$$
\mathrm{h}=\mathrm{K}_{2} \times \mathrm{q}_{\mathrm{e}}^{2}
$$

The equilibrium sorption capacity $\left(\mathrm{q}_{\mathrm{e}}\right)$ and the initial sorption rate (h) along with the pseudo second order constant $\mathrm{K}_{2}$ can be determined from slope and intercept of the plot of $\mathrm{t} /$ $\mathrm{q}_{\mathrm{t}}$ versus $\mathrm{t}$. The graph of pseudo second order model has been represented in Fig. 10(b). Biosorption of As(III) and As(V) ions onto mosambi peel biomass follows pseudo-second order model best with high linear regression coefficients $\left(\mathrm{R}^{2}\right)$ for both $\mathrm{As}(\mathrm{III})$ and $\mathrm{As}(\mathrm{V})$ ions, which shows a good representation between the experimental and the calculated $\mathrm{q}_{\mathrm{e}}$ values ${ }^{22}$. Besides, the correlation coefficient values for the secondorder kinetic model were almost equal to unity for all cases as can be seen in Table-4.

Thermodynamic studies: Thermodynamic parameters such as free energy change $\left(\Delta \mathrm{G}^{\mathrm{o}}\right)$, enthalpy change $\left(\Delta \mathrm{H}^{\mathrm{o}}\right)$ and entropy change $\left(\Delta S^{\circ}\right)$ for the biosorption of arsenic from aqueous 
TABLE-4

KINETIC MODEL PARAMETERS FOR As(III) and As(V) IONS ONTO MOSAMBI PEEL BIOMASS AT $8 \mathrm{~h}$ AND $313 \mathrm{~K}$

\begin{tabular}{ccccccc}
\hline \multirow{2}{*}{ Metal ions } & $\begin{array}{c}\text { Experimental } \\
\mathrm{q}_{\mathrm{e}}(\mathrm{mg} / \mathrm{g})\end{array}$ & $\begin{array}{c}\text { Calculated } \mathrm{q}_{\mathrm{e}} \\
\left(\mathrm{mg} \mathrm{g}^{-1}\right)\end{array}$ & $\mathrm{K}_{1}\left(\mathrm{~min}^{-1}\right)$ & $\mathrm{R}^{2}$ & $\begin{array}{c}\text { Palculated q } \\
\left(\mathrm{mg} \mathrm{g}^{-1}\right)\end{array}$ & $\begin{array}{c}\mathrm{K}_{2} \\
\left(\mathrm{~g} \mathrm{mg}^{-1} \mathrm{~min}^{-1}\right)\end{array}$ \\
\hline As(III) & 2.12 & 1.35 & 0.41 & 0.970 & 2.25 & 0.23 \\
As(V) & 3.32 & 2.55 & 0.68 & 0.982 & 3.47 & 0.999 \\
\hline
\end{tabular}

solutions and synthetic wastewater solution were determined using the following equations ${ }^{34,35}$.

$$
\Delta \mathrm{G}^{\mathrm{o}}=-\mathrm{RT} \ln \mathrm{K}
$$

where $\mathrm{K}$ is the distribution coefficient, which can be replaced by the Langmuir constant, $\mathrm{K}_{\mathrm{L}}$.

$$
\ln \mathrm{K}=\frac{\Delta \mathrm{S}^{\mathrm{o}}}{\mathrm{R}}-\frac{\Delta \mathrm{H}^{\mathrm{o}}}{\mathrm{RT}}
$$

Plot of $\ln \mathrm{K}$ versus $1 / \mathrm{T}$ gives the thermodynamic parameters $\left(\Delta \mathrm{H}^{\circ}\right)$ and $\left(\Delta \mathrm{S}^{\circ}\right)$ as shown in Fig. 11.

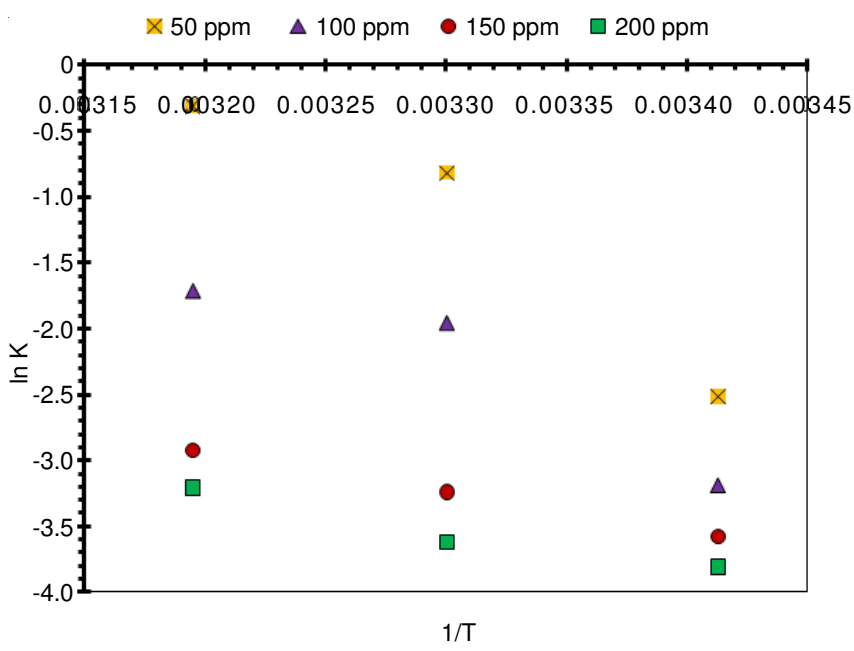

(a)

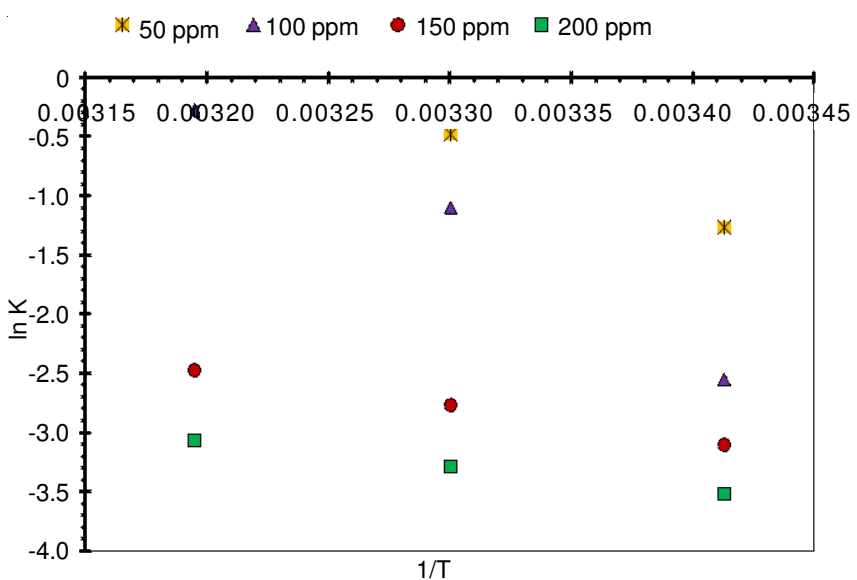

(b)

Fig. 11. Plot of $\ln \mathrm{K}$ versus $1 / \mathrm{T}$ for estimation of thermodynamic parameters for arsenic ions sorption onto mosambi peel biomass surface at different temperatures. (a) $\mathrm{As}(\mathrm{III})$ ion and (b) $\mathrm{As}(\mathrm{V})$ ion

In order to determine the thermodynamic feasibility and the thermal effects of the sorption, the Gibbs free energy $\left(\Delta \mathrm{G}^{\mathrm{o}}\right)$, the entropy $\left(\Delta \mathrm{S}^{\circ}\right)$ and the enthalpy $\left(\Delta \mathrm{H}^{\circ}\right)$ were calculated. The $\Delta \mathrm{G}^{\mathrm{o}}$ represents the fundamental criterion to determine if a

\begin{tabular}{|c|c|c|c|c|}
\hline \multicolumn{5}{|c|}{$\begin{array}{c}\text { TABLE-5 } \\
\text { THERMODYNAMIC PARAMETERS FOR As(III) ONTO } \\
\text { MOSAMBI PEEL BIOMASS AT VARIOUS TEMPERATURES } \\
\left(\mathrm{C}_{\mathrm{i}}=50-200 \mathrm{mg} \mathrm{L}^{-1}, \mathrm{t}_{\mathrm{c}}=4 \mathrm{~h} \text { AND } 150 \mathrm{rpm}\right)\end{array}$} \\
\hline \multirow[b]{2}{*}{ Metal ion } & \multirow{2}{*}{$\begin{array}{c}\text { Temperature } \\
\text { (K) }\end{array}$} & \multicolumn{3}{|c|}{ Thermodynamic parameters } \\
\hline & & $\begin{array}{c}\Delta \mathrm{G}^{\circ} \\
\left(\mathrm{kJ} \mathrm{mol}^{-1}\right) \\
\end{array}$ & $\begin{array}{c}\Delta \mathrm{H}^{\circ} \\
\left(\mathrm{kJ} \mathrm{mol}^{-1}\right) \\
\end{array}$ & $\begin{array}{r}\Delta \mathrm{S}^{\mathrm{o}}(\mathrm{kJ} \\
\left.\mathrm{mol}^{-1} \mathrm{~K}^{-1}\right)\end{array}$ \\
\hline \multirow{3}{*}{ As(III) } & 313 & -87.36 & \multirow{3}{*}{45.84} & \multirow{3}{*}{0.13} \\
\hline & 303 & -86.04 & & \\
\hline & 293 & -84.71 & & \\
\hline \multirow{3}{*}{$\operatorname{As}(\mathrm{V})$} & 313 & -41.24 & \multirow{3}{*}{24.03} & \multirow{3}{*}{0.06} \\
\hline & 303 & -41.06 & & \\
\hline & 293 & -40.5 & & \\
\hline
\end{tabular}
process occurs spontaneously. From Table-5, the negative value of Gibbs free energy $\left(-\Delta G^{\circ}\right)$ obtained from the experimental results confirmed the feasibility of the adsorption process and the spontaneous nature of the sorption ${ }^{36}$. Positive value of entropy $\left(\Delta \mathrm{S}^{\circ}\right)$ and enthalpy $\left(\Delta \mathrm{H}^{\circ}\right)$ indicates the endothermic nature of the process ${ }^{22}$.

\section{Conclusion}

Present investigation established the economical feasibility of using mosambi peel as a biosorbent for the removal of arsenic from aqueous solution. It was found that acidic conditions ( $\mathrm{pH} 4$ ) were favourable for the removal of $\mathrm{As}(\mathrm{V})$ ion and nearly neutral ( $\mathrm{pH}$ 6) were favourable for the removal of As(III) ion. At optimized conditions, maximum uptake capacity of $2.12 \mathrm{mg} \mathrm{g}^{-1}$ for As(III) ion and $3.32 \mathrm{mg} / \mathrm{g}$ for $\mathrm{As}(\mathrm{V})$ ion were obtained at $313 \mathrm{~K}$ and the percentage removal of As(III) and As(V) ions were 84.92 and $89.10 \%$, respectively. Further, increase in temperature of solute and dosage of biosorbent increased the removal of arsenic species. The effects of temperature and biosorbent dosage also played imperative role in arsenic ions removal. The equilibrium sorption data was best represented by Freundlich isotherm model. Studies of the biosorption of arsenic ions onto the surface of MP biomass revealed that the biosorption process followed pseudo second order kinetic model. Thermodynamic properties $\left(-\Delta \mathrm{G}^{\mathrm{o}},+\Delta \mathrm{S}^{\mathrm{o}}\right.$ and $+\Delta \mathrm{H}^{\circ}$ ) obtained from the experimental results confirmed the feasibility of the adsorption process and the endothermic nature of the sorption.

\section{REFERENCES}

1. V. Straskraba and R.E. Moran, Mine Water Environ., 23, 45 (2006).

2. P.L. Smedley and D.G. Kinniburgh, Appl. Geochem., 17, 517 (2002).

3. C.K. Jain and I. Ali, Water Res., 34, 4304 (2000).

4. P. Mondal, C.B. Majumder and B. Mohanty, J. Hazard. Mater., 153, 588 (2008).

5. T.S.Y. Choong, T.G. Chuah, Y. Robiah, F.L.G. Koay and I. Azni, Desalination, 217, 139 (2007).

6. D. Mohan and C.U. Pittman, J. Hazard. Mater., 142, 1 (2007).

7. C.J. Shih and C.F. Lin, Chemosphere, 53, 691 (2003).

8. O.D. Uluozlu, M. Tuzen, D. Mendil and M. Soylak, Food Chem. Toxicol., 48, 1393 (2010).

9. T.K. Naiya, P. Chowdhury, A.K. Bhattacharya and S.K. Das, Chem. Eng. J., 148, 68 (2008). 
10. P. Kumari, P. Sharma, S. Srivastava and M.M. Srivastava, Int. J. Mineral Proc., 78, 131 (2006).

11. C.T. Kamala, K.H. Chu, N.S. Chary, P.K. Pandey, S.L. Ramesh, A.R.K Sastry and S.K. Chandra, Water Res., 39, 2815 (2005).

12. D. Ranjan, M. Talat and S.H. Hasan, J. Hazard. Mater., 166, 1050 (2009).

13. J.A. Baig, T.G. Kazi, A.Q. Shah, G.A. Kandhro, H.I. Afridi, S. Khan and N.F. Kolachi, J. Hazard. Mater., 1, 13 (2010).

14. G.S. Murugesan, M. Sathiskumar and K. Swaminathan, Bioresour. Technol., 97, 483 (2006).

15. C.A. Basha, N.S. Bhadrinarayana and N. Anantharaman, J. Hazard. Mater., 152, 71 (2008).

16. M. Urik, P. Littera, J. Sevc, M. Kolencik and S. Cernansky, Int. J. Environ. Sci. Technol., 6, 451 (2009).

17. A.I. Zouboulis and I.A. Katsoyiannis, Environ. Int., 31, 213 (2005).

18. M. Thirumavalavan, Y.-L. Lai, L.-C. Lin and J.-F. Lee, J. Chem. Eng. Data, 55, 1186 (2010).

19. J. Madarasz, M. Okuya, P.P. Varga, S. Kaneko and G. Pokol, J. Anal. Appl. Pyroly., 79, 479 (2007).

20. A. Kara, L. Uzun, N.B. Sirli and A. Denizli, J. Hazard. Mater., 106, 93 (2004).

21. H. Arslanoglu, H.A. Soner and F. Tumen, Bioresour. Technol., 99, 2699 (2008).

22. M.I. Khaskheli, S.Q. Memon, A.N. Siyal and M.Y. Khuhawar, Waste Biomass Valor, DOI 10.1007/s12649-011-9081-7 (2011).

23. G. Socrates, Infrared Characteristic Group Frequencies, WileyInterscience Publication, NY (1980).

24. T. Budinova, D. Savova, B. Tsyntsarski, C.O. Ania, B. Cabal, J.B. Parra and N. Petrov, Appl. Surf. Sci., 225, 4650 (2009).

25. Y.N. Chen, L.Y. Chai and Y.D. Shu, J. Hazard. Mater., 160, 168 (2008).

26. M. Khormaei, B. Nasernejad, M. Edrisi and T. Eslamzadeh, J. Hazard. Mater., 149, 269 (2007).

27. P.T.M. Ghazvini and S.G. Mashkani, Bioresour. Technol., 100, 2361 (2009).

28. Y. Li, J. Wang, Z. Luan and Z. Liang, J. Hazard. Mater., 177, 131 (2010).
29. S.K. Papageorgiou, F.K. Katsaros, E.P. Kouvelos, J.W. Nolan, H.L. Deit and N.K. Nick, J. Hazard. Mater., 137, 1765 (2006).

30. M.S. Bilgili, J. Hazard. Mater., 137, 157 (2006).

31. L. Daina, Q. Oliveira, G. Maraisa, C.A.O. Luiz and R.G. Guilherme, J. Hazard. Mater., 151, 280 (2008).

32. S. Gueu, B. Yao, K. Adouby and G. Ado, Int. J. Environ. Sci. Technol., 4, 11 (2007).

33. T.K. Radoicic and S. Raicevic, Chem. Eng. J., 160, 503 (2000).

34. V.B. Bart and V. Carlo, Environ. Pollut., 122, 435 (2003).

35. S. Suresh, V.C. Srivastava and I.M. Mishra, J. Chem. Eng. Data, 56, 811 (2011)

36. T. Budinova, N. Petrov, M. Razvigorova, J. Parra and P. Galiatsatou, Ind. Eng. Chem. Res., 45, 1896 (2006).

37. C.A. Basha, N.S. Bhadrinarayana and N. Anantharaman, J. Hazard. Mater., 152, 71 (2008)

38. M. Urik, P. Littera, J. Sevc, M. Kolencik and S. Cernansky, Int. J. Environ. Sci. Technol., 6, 451 (2009).

39. A.I. Zouboulis and I.A. Katsoyiannis, Environ. Int., 31, 213 (2005).

40. D. Prokhrel and T. Viraraghavan, Sep. Sci. Technol., 43, 3545 (2008).

41. S. Deng and Y.P. Ting, Langmuir, 21, 5940 (2005).

42. P. Mondal, B. Mohanty and C.B. Majumder, AIChE J., 55, 1860 (2009).

43. A.G. Gault, D.R. Cooke, A.T. Townsend, J.M. Charnock and D.A. Polya, Sci. Tot. Environ., 345, 219 (2005)

44. C.S. Jeon, K. Baek, J.K. Park, Y.K. Oh and S.D. Lee, J. Hazard. Mater., 163, 804 (2009).

45. S.A. Wasay, M.D.J. Haron and S. Tokunaga, Water Environ. Res., 68, 295 (1996).

46. K. Sultan and K. Dowling, Water Air Soil Pollut., 169, 355 (2006).

47. M.P. Miramontes, R.G.B. Margulis and A.P. Hemandez, Fluoride, 36, 122 (2003).

48. S. Chakraborty, S. Bhattacharjee, G. Maity, V. Dureja and V. Gupta, Water Res., 36, 625 (2002).

49. S. Bhattacharjee, S. Chakravarty, S. Maity, V. Dureja and V. Gupta, Chemosphere, 58, 1203 (2005). 